\title{
WIND POWER, DISCOURSE \\ COALITIONS AND \\ CLIMATE CHANGE: \\ BREAKING THE STALEMATE?
}

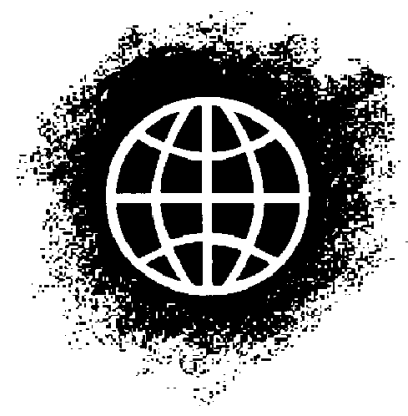

Joseph Szarka*

Department of European Studies, University of Bath, UK

In order to analyse the discourse coalitions existing within the wind sector in Britain, Denmark and France, this article first outlines a theoretical framework for policy analysis in terms of four discourse 'ideal types' and two categories of coalition behaviour. After examination of European and national energy policies, it goes on to map the main discourse coalitions in the wind sector and considers why their interaction often leads to conflict. The conclusion invites reassessment of the uses to which the policy arguments - particularly those related to climate change - have been put, and offers tentative proposals for reducing blockages. Copyright (c) 2004 John Wiley \& Sons, Ltd and ERP Environment.

\footnotetext{
* Correspondence to: Dr. Joseph Szarka, Senior Lecturer, Department of European Studies, University of Bath, Claverton Down, Bath BA2 7AY, UK.

E-mail: J. P. Szarka@bath.ac.uk
}

Copyright @ 2004 John Wiley \& Sons, Ltd and ERP Environment

\section{INTRODUCTION}

$\mathrm{W}$ ind power generates not just electricity, but also strong views. Drawing on interviews with representatives of public and private organizations in Britain, Denmark and France, as well as on published literature and 'grey' sources, this article considers the coalitions and conflicts that have developed in relation to wind power. Energy companies, international NGOs and central governments now use a common discourse stressing the role of renewables - and particularly wind - in fighting climate change. Meanwhile nature conservation organizations are challenged by the need to balance immediate disruptions to sensitive ecosystems against long-term sustainability issues. Opposition from local residents groups has increased as planning applications for wind farms have multiplied.

This article's main aim is to analyse the discourse coalitions existing within the wind sector. It first outlines a theoretical framework for policy discourse analysis, and then examines European and national energy policies. It then maps the main discourse coalitions and 
considers why their interaction leads to conflict. The conclusion invites reassessment of the uses to which the policy arguments particularly those related to climate change have been put, and offers tentative proposals for reducing blockages.

\section{THEORIZING POLICY DISCOURSE}

The policy studies literature has shown great interest in the role of discourse since the policy process involves argumentation and persuasion in both the setting of priorities and the identification of instruments. Because the choice between competing policy options advantages some social or economic actors over others, and because environmental impacts in terms of ecological systems and life situations are varied, interests and values lie at the core of policy debates. Analysis of interests and values requires consideration of the discourses that express them. This insight has yielded the 'argumentative turn in policy analysis' (Fischer and Forester, 1993).

Whilst acknowledging that the substance of arguments is crucial, discourse analysis also considers the strategic manners in which policy issues are framed. Thus Majone (1989, pp. 23-24) contended that 'the most important function both of public deliberation and of policy-making is defining the norms that determine when certain conditions are to be regarded as policy problems'. In other words, although a policy frame identifies what the problem is, its primary function is to tell us we have a problem. Framing thus becomes a process of 'selecting, organising, interpreting, and making sense of a complex reality to provide guideposts for knowing, analysing, persuading and acting' (Rein and Schön, 1993, p. 146). In negotiating frames, actors seek to fuse a complex reality with the discourse they use to represent it. An apparently seamless overlap between a set of problematic conditions and its representation is the sign of an accomplished discourse strategy. Although achieving this overlap is the goal of partisan actors (as it achieves their ends by neutralizing dissent), the enterprise always meets two limits. The first is ontological, since the ground of being never admits a single construction, representation or interpretation. Complex realities always give rise to alternative and contested accounts. The second is political in that biased framing will offend the values and interests of the greater number. Due to these limits, a seamless overlap between 'discourse' and 'reality' transpires to be an illusion. The discourse analyst's role is to unpick the hidden seams, reveal the contours of individual discourses and identify the dynamics of interaction between the actors who originate them. A core method is to apply a classification. Discourses are classified by type not to immobilize living arguments on an entomologist's pin, but to gain analytical purchase on the slippery surfaces of policy arguments and flip them over for viewing from different angles.

Dryzek (1997) identified nine types of environmental discourse: two dealt with global limits, three aimed at 'business as usual' problem solving, two related to the sustainability transition and two expressed green radicalism. His analysis largely concerned the macro-level of discourse content, with few examples of actor behaviour. In relation to environmental planning case-studies, Rydin (2003, pp. 96-114) set out a three-part discourse typology comprised of scientific rationality, economic rationality and communicative rationality. The first two developed within bodies of technical expertise, whilst the third is 'a politico-legal discourse based on a philosophy of rights' (Rydin, 2003, p. 109) which connects to contemporary debates on the conduct of democracy and the scope for citizen choice. She cross-links these discourses to the 'three pillars' of the sustainable development agenda: 'these three dimensions - the environmental, the economic, and the social - are closely related to the three rationalities that have been examined in terms of their individual legitimation of environmental planning. 
Scientific rationality supports the claims of environmental sustainability; economic rationality relates directly to the economic dimension; and communicative rationality justifies the involvement of a broad range of actors and consideration of a wide range of perspectives, a key link to social sustainability' (Rydin, 2003, p. 167).

Rydin's and Dryzek's discourse categorizations present interesting contrasts. Dryzek's is apparently richer because it identifies discourse positions, but Rydin's has the merit of parsimony, whilst its application to air quality management, housing land policy and Local Agenda 21 demonstrates its relevance for a range of policy contexts. This indicates success in identifying discourse 'ideal types'. Yet there is arguably a fourth discourse 'ideal type', which - though not absent from the studies referenced - is not flagged as a specific category. This is the ethical-normative frame. Ethical-normative discourse stresses the responsibilities, obligations and behavioural norms of individuals and organizations. In today's multicultural contexts it comes in many varieties, drawing on world religions, civic cultures and political ideologies. The latter now includes environmentalism and the sustainability literature, where notions such as 'environmental justice' and 'intergenerational equity' are used to legitimatize (or critique) policy options and modes of societal behaviour.

Yet identification of discourse 'ideal types' is proposed only as phase one in a policy analysis. Phase two relates to discourse in practice, namely who uses particular arguments, how they are used, and to what purposes. Since discourse assumes communication and reciprocity, the ways in which actors interact will reflexively modify their statements and strategies. Here the concept of 'discourse coalitions' as developed by Hajer $(1993,1995)$ is fruitful. In his definition, 'a discourse coalition is thus the ensemble of a set of story lines, the actors that utter these story lines, and the practices that conform to these story lines, all organized around a discourse' (Hajer, 1993, p. 47). The value of this approach is that it illuminates how discourse becomes a means to political action.

However, the problem with Hajer's formulation is that he underplays the notion of 'coalition'. Coalition behaviour is generally understood as concerted action directed at mutually beneficial goals. Yet he claims that actors can 'reproduce or fight a given bias without necessarily orchestrating or coordinating their actions' (Hajer, 1993, p. 48). This conceptualization helpfully widens the remit of 'discourse coalitions' to cases of 'objective alliances' or 'strange bedfellows' (e.g. arms-length relationships involving little or no communication on common positions, possibly characterized by mutual mistrust), whilst allowing inclusion of international developments where actors use the same discourse but act autonomously within their respective territories. Nevertheless, it blunts the cutting edge of the coalition idea as concerted action.

On the other hand, the 'advocacy coalition framework' (ACF) postulates that coalition membership can be positively identified by the fact that actors engage in some nontrivial degree of co-ordinated activity in pursuit of common policy objectives' (Sabatier and Jenkins-Smith, 1999, p. 127). Thus Sabatier's ACF is most applicable when organizations take action in concert, but Hajer's 'discourse coalitions' concept has hermeneutic value when actors sing in chorus - but not necessarily in the same choir. In other words, 'advocacy coalitions' are taken to be a sub-set of 'discourse coalitions', but of a significant and powerful kind. These theoretical reflections will now be applied to wind power.

\section{EUROPEAN AND NATIONAL ENERGY POLICY DISCOURSES}

The uptake of renewables has been promoted by three main arguments: 
- climate change analyses that stress the release of greenhouse gases (GHGs) from fossil fuel burning as the source of climatic disruption;

- environmentalist criticisms of pollution and risk caused by fossil and nuclear energy sources;

- concerns over the security of supply of traditional fuels stemming from (a) political instability in producing regions and (b) signs that oil and gas prices are escalating under conditions of accelerating depletion.

The first two arguments are based on 'scientific rationality'. 'Environmentally benign' and locally available renewables are being promoted to substitute (or just complement) traditional fuels. Ethical-normative discourse is usually present too, in notions such as the "polluter pays' principle. The third argument stems from the discourse of 'economic rationality' concern with the supply and demand equation is combined with implicit acknowledgement of the 'resource limits' thesis (see Meadows et al., 1972).

Whilst all three arguments have been used for promoting wind power, stress is now placed on the first by the pro-wind lobby. This is because of the success of climate change discourse, with its insistence on anthropogenic emissions as the catalyst of a runaway greenhouse effect. This discourse coalition aligns the UN (as evidenced at Rio and Kyoto), national governments and NGOs. The prominence given to 'global warming' by the media from the late 1980s created a ground-swell of public opinion favourable to reactive policy measures. Governments have chosen mitigation over adaptation, emphasizing the slowing of climate change, rather than anticipating ways to live with its consequences. ${ }^{1}$ However, scientific explanations of climate change offer only rough indications as to which technologies or policies should be privileged for mitigation

${ }^{1}$ For discussion of the mitigation versus adaptation choice, see Boehmer-Christiansen and Kellow, 2002. purposes. This indeterminacy opens the door to the influence of other discourses. We next turn to landmarks in climate change policy to see how this indeterminacy has presented opportunities for wind power.

The major advance remains the 1997 Kyoto Protocol, which called for GHG cuts by 'Annex 1 ' countries of $5.2 \%$ by reference to a 1990 baseline, to be achieved by various 'flexible mechanisms'. Because of the largely untried nature of the latter, progress to implementation has been slow. Although the EU is now putting into place a GHG emissions trading system (based on Directive 2003/87/EC), the policy response previously favoured state-centred measures. The main instrument is Directive 2001/77/EC, which set targets for each member state regarding electricity generation from renewables. The UK target for 2010 is 10\% (as compared to 1.7\% in 1997), for France 21\% (up from 15\%) and for Denmark 29\% (up from $8.7 \%)$. The directive's targets are indicative; they relate to all categories of renewables (not just wind), but no equivalent directive exists for using renewables for purposes other than generating electricity.

The translation of EU targets into national policies has taken two turns. First, governments seeking to project an environmentally friendly image have glossed the indicative targets as if firm and binding. Here an ethical-normative discourse operates, emphasizing environmental obligations, collective responsibilities and a measure of aspirational idealism. Second, although generating technologies to attain national targets were not specified in the directive, considerable recourse to wind power is assumed. This represents a major advance for the wind lobby, which has positioned itself as 'ahead' of competitor technologies. Whilst recourse to small-scale hydro-electricity remains possible, major expansion is unfeasible as the best sites are already exploited. Other technologies are 'immature'. Large-scale wave generation remains impracticable (for the moment), whilst grid-connected photovoltaic generation entails 
excess costs. Consequently, a substantial share of the increase in renewable-based electricity is budgeted to come from wind. A representative estimate for France to meet its 2010 EU target is $7000-14000 \mathrm{MW}$ of wind capacity (Birraux and Le Déaut, 2001, p. 268). For the UK, the $10 \%$ target was estimated to require approximately $10000 \mathrm{MW}$ of renewable capacity, with the Secretary of State for Trade and Industry (2003, pp. 54-55) stating that 'onshore and offshore wind may be the largest contributor to the renewables generation mix in 2010'. To reach this leading position, pro-wind campaigners have stressed that the technology is competitive once 'external costs' associated with conventional fuels are factored into the equation. However, since most 'externalities' are not costed (notably GHG or sulphur emissions, storage of spent radioactive materials etc.), wind power has relied on subsidies to offset its higher generation costs.

The policy instrument giving the greatest boost has been the 'feed-in tariff', where governments set a guaranteed price for windgenerated electricity. An assured cash flow gives developers predictable profits and easy access to finance capital. The incentive power of this instrument is demonstrated by the fact that countries using it over the long-term Denmark, Spain and Germany - have the greatest wind-power capacity (respectively 3110MW, 6202 MW and 14609MW in 2003). ${ }^{2}$ On the other hand, Britain and France in the 1990s operated trial policies based on calls to tender, namely the Non-Fossil Fuel Obligation (NFFO) and EOLE 2005. ${ }^{3}$ These provided lower incentives to developers, and capacity remained limited: 649 MW in Britain and 239 MW in France in 2003.

\section{Denmark}

Wind power expansion in Denmark was facilitated by a societal movement in favour of

\footnotetext{
${ }^{2}$ Figures from an EWEA press release, 3 February 2004.

${ }^{3}$ For discussions on the NFFO, see Mitchell, 1995, 2000; Helm, 2002. On EOLE 2005, see Benard, 1998; Laali and Benard, 1999.

wind, involving individual and co-operative ownership of turbines, and the growth of an indigenous turbine industry. ${ }^{4}$ Both have their roots in a rural economy characterized by a self-help ethos, pragmatism and technological incrementalism. The wind turbine industry was spurred by a 'first mover' advantage, by the failures of competitors (notably in the USA) and by opportunities for export, all buoyed up by favourable public policies. Denmark's implementation of a 'feed-in tariff' attained two categories of policy objectives. One related to energy policy, to the need to respond to oil price shocks and improve security of supply whilst restructuring the electricity sector into a more environmentally friendly configuration. The other related to industrial policy and the acceleration of the shift from an agricultural to a manufacturing and service based economy. These drivers were in place before climate change discourse came to prominence in the 1990s.

In 1996 the Danish government published Energy 21, which set targets for $\mathrm{CO}_{2}$ reductions of $20 \%$ by 2005, and $50 \%$ by 2030 (Danish Environment and Energy Ministry, 1996, pp. 18-19). Within the framework of the 1997 Kyoto Protocol and the 1998 EU burden sharing agreement, Denmark agreed a $21 \%$ cut in GHGs from 1990 levels for the period 2008-2012. However, by 1999, the government was worried about a shortfall of $3.5 \%$, since $\mathrm{CO}_{2}$ emissions were falling, but at lower than expected rates (Danish Environment and Energy Ministry, 1999, pp. 7-11). In 2003 the situation reached crisis point. Total emissions were on course to exceed Kyoto targets by 20-25 million tonnes of $\mathrm{CO}_{2}$ equivalent, corresponding to 25-30\% of emissions (Danish Government, 2003, p. 3). The electricity sector was responsible for almost $40 \%$ of emissions (Danish Government, 2002, p. 22), due to heavy reliance on fossil combustion. Fuel shares in electricity generation in 1999 were

\footnotetext{
${ }^{4}$ For discussion, see Gipe, 1995; Jørgensen and Karnøe, 1995; Brundt and Spooner, 1998; Nielsen, 2002.
} 
coal $53 \%$, natural gas $23 \%$, oil $14 \%$ and renewables 10\% (Grohenheit, 2002, p. 108). Although wind has taken an increasing share, emissions cuts have not met expectations because 'a substantial expansion of wind power [...] has not been balanced with corresponding reductions in fossil-based electricity production. Denmark therefore has significant surplus capacity' (Danish Government, 2003, p. 18). That capacity has been turned to electricity exports (see Grohenheit, 2002, for discussion). When drought reduces production in the hydro systems of its Nordic neighbours, Denmark has the opportunity to sell them electricity. However, in 2003 the weather conditions that produced drought also induced low levels of wind. Danish electricity exports came from fossil fuels, being responsible for 10 million tonnes of its anticipated 20-25 million tonnes of excess $\mathrm{CO}_{2}$ (Danish Government, 2003, p. 12). Part of the Danish problem is that whilst the integrated Nordic electricity market requires this balancing of renewable and fossil sources, Denmark alone carries the $\mathrm{CO}_{2}$ burden of its exports. The government is seeking solutions via the Kyoto 'flexible mechanisms' as potentially more cost effective (Danish Government, 2003, p. 4) and has engaged in a policy review of wind. In 1999-2000, the announced reform of the feedin tariff produced a dash to build followed by slump. However, in 2003-2004, onshore 'repowering' schemes were launched to replace old, inefficient turbines with more powerful installations, together with calls for tender for large offshore wind farms. Planned extra capacity is around $750 \mathrm{MW}$, which could take wind-generated electricity to $25 \%$ of consumption in 2010 (Wind Directions, 2004, p. 8).

\section{France}

Around $90 \%$ of French electricity is produced from GHG free sources (depending on year about $75 \%$ nuclear, $15 \%$ hydro). The remainder is fossil fuel (including 6\% coal) and is used to respond to demand peaks. Thus the scope to displace fossil fuel by wind is extremely limited. Since the carbon content of French electricity is significantly lower than elsewhere, ${ }^{5}$ France has no reduction target under the Kyoto agreement: the objective is to stabilize annual GHG emissions at their 1990 level of $144 \mathrm{Mt}$ Ce. However, projections for 2008-2012 indicated an overshoot in the absence of other measures (Gouvernement Français, 2000). Substitution of coal by gas would cut the French electricity sector's GHG emissions by half to approximately $5 \mathrm{Mt} \mathrm{Ce}$, with the greatest scope lying in France's overseas territories (de Gouvello, 2002, p. 138). Though valid, this would only dent the projected overshoot of $15-25 \mathrm{Mt} \mathrm{Ce}$, most of which comes from transport and the residential sector. Even in a context of demand growth (+1-2\% per year on current estimates), the potential for wind power to improve French GHG balances is slight. Thus climate change discourse as a pro-wind driver has limited relevance in the French context. Other pro-wind arguments exist however - such as opposition to nuclear power, which may explain why Environment Minister Cochet, a leading 'Green', introduced a feed-in tariff in 2001. It offers a headline rate of 8.38 eurocents per $\mathrm{kWh}$ for five years, with degressive rates for 10 years thereafter. These guaranteed prices apply only to wind farms of a maximum capacity of $12 \mathrm{MW}$. The government has put out calls for tender for large wind farms, perhaps in the 100 MW category.

\section{United Kingdom}

Britain has consistently refused the feed-in tariff route, but in 2002 introduced the Renewables Obligation, which forces suppliers to contract $5 \%$ of electricity from renewables in 2003 and $10 \%$ by 2010 . Under Kyoto, the UK is committed to a $12.5 \%$ cut in total GHG emissions. By 2000, Britain achieved a $22 \%$

${ }^{5}$ For France, $20 \mathrm{gC} / \mathrm{kWh}$ as against a European average of $120 \mathrm{gC} / \mathrm{kWh}$ (de Gouvello, 2002, p. 135). 
reduction, mainly due to the switch from coal to gas in electricity generation (Steen and Vrolijk, 2002, p. 230). To forge towards 'a low carbon economy', the government set the target of a $20 \%$ cut by 2010 and accepted the recommendation from the Royal Commission on Environmental Pollution to seek reductions of $60 \%$ by 2050 (Secretary of State for Trade and Industry, 2003), since the Commission argued that 'there is a moral imperative to act now' (quoted by Parker, 2002, p. 34). These targets require significant subsidies to renewables, which for the period 2002-06 were estimated at $£ 250$ million pounds (Secretary of State for Trade and Industry, 2003, p. 103). The implication is that $30-40 \%$ of electricity would come from renewables in 2050 (Secretary of State for Trade and Industry, 2003, p. 44). This compares with $3 \%$ from renewables in 2002, when gas generated $38 \%$, coal $32 \%$, nuclear $23 \%$ and oil and other $4 \%$.

The Secretary of State for Trade and Industry (2003, p. 51) described planning as 'one of the big obstacles to new renewables'. Another obstacle is NETA (New Electricity Trading Arrangements), which has 'discouraged further development of cogeneration capacity and has badly affected renewables generators' (Steen and Vrolijk, 2002, p. 228). This is because NETA till 2002 required generators to predict output at least three and a half hours in advance (on pain of incurring penalties), a requirement that producers from intermittent sources could not always meet. Moreover, NETA was designed to drive prices down, which exposed the limited competitiveness of wind.

\section{Overview}

Since the 2001 European directive, the 'wind rush' has mostly been justified by climate change discourse. This is surprising for several reasons. First, the original drivers in the case of Denmark, the pioneer in the wind sector, were issues of security of supply and environmental friendliness. Second, climate change discourse has marginal relevance to French electricity generation, which is 90\% GHG free. Third, only Britain seems able to exceed its GHG targets - due to substitution of coal not by renewables but by gas, whereas Denmark and France may not attain theirs, despite greater proportions of GHG-free generation. In summary, beneath the surface compatibility between climate change arguments and the promotion of wind power in Denmark, France and Britain lurk disjunctions between the discourse and reality. This has contributed to conflictual relations within the wind sector.

\section{DISCOURSE COALITIONS AND WIND POWER}

Field research in Britain, Denmark and France has allowed the identification of three main categories of actor in the wind sector. The first is the pro-wind coalition, comprised of industrialists, national governments, international NGOs and 'green' parties. The second is an intermediate grouping of conservationist organizations, having no inherent interests for or against the wind sector, but who have been caught up in its expansion. The third is the anti-wind movement, organized into associations at local and national levels, which has the aim of braking wind-power development or halting it altogether.

\section{The Pro-Wind Coalition}

Various organizations have mobilized in favour of wind power. These include the International Energy Agency, which states that its 'commitment to wind energy dates back to 1977' (IEA, 2003, p. 9) and produces analyses supporting wind power expansion. The European Wind Energy Association (EWEA) describes itself as the 'international voice of the wind industry', representing the interests of manufacturers, developers, owners and utilities. At national levels, the industry is represented by the Danish Wind Industry Association (DWIA), the British Wind Energy 
Association (BWEA), France Energie Eolienne (FEE) etc. The wind associations do not generally seek to mobilize public opinion in favour of wind. Rather, they lobby policy-makers for favourable operating conditions.

The drive for public mobilization has largely come from major NGOs and political ecology activists. 'Green' parties around Europe have been enthusiastic supporters of wind energy. Likewise, Greenpeace and Friends of the Earth have argued for wind power as an alternative to nuclear energy. These international NGOs and the wind industry now speak a common discourse, emphasizing the role of wind in fighting climate change. Their arguments stress the 'climate change imperative' (EWEA and Greenpeace, 2003, p. 12) and the need to 'cut emissions of $\mathrm{CO}_{2}$ to avert catastrophe' (FoE, 2002). EWEA and Greenpeace (2003) have jointly produced A Blueprint to Achieve $12 \%$ of the World's Electricity from Wind Power by 2020, a document that exhorts policy-makers to invest in wind power and argues for its economic viability and environmental benefits, including claims for very substantial GHG reductions, ${ }^{6}$ whilst asking for legally binding targets for renewables. Taken in combination, these elements reveal the existence of an 'advocacy coalition', considered as a range of actors sharing 'some nontrivial degree of $\mathrm{CO}^{-}$ ordinated activity in pursuit of common policy objectives' (Sabatier and Jenkins-Smith, 1999, p. 127).

In addition, some major conservation organizations have made accommodations with wind power. A guidance document signed off by the chief executives of English Nature, RSPB, WWF-UK and BWEA (2001, p. 6) notes that wind farms are often sited in locations that 'comprise some of the most important and sensitive habitats', but on the other hand 'greenhouse gases and acidifying gases have damaging impacts on biodiversity; the

\footnotetext{
${ }^{6}$ 'By 2040, wind power will contribute an annual reduction of 4860 million tonnes $\mathrm{CO}_{2}$, resulting in a cumulative reduction of 85911 million tonnes $\mathrm{CO}_{2}{ }^{\prime}$ (EWEA and Greenpeace, 2003, p. 40).
}

development of wind farms is a key means of reducing emissions and should be supported as such'. Further, the document is presented as a 'tool' for 'statutory agencies and NGOs in their policy advocacy work' (English Nature et al., 2001). The core proposition is that local disruptions to wildlife caused by wind farms are dwarfed by the global ecological fall-out of climate change. However, the message is overlaid by an evangelical mission to spread the word to policy-makers and the public. Through their efforts 'wind power, like the whale, has become a symbol of green politics and environmental consciousness' (Brundt and Spooner, 1998, p. 280). By an effect of metonymy, wind power has come to stand for green energy and the three-bladed wind turbine has attained the status of an icon.

\section{Dilemma and Dissent}

Pro-wind lobbying has created a dilemma for nature conservation organizations which believe a balance must be struck between the immediate damage caused by wind farms and long-term sustainability issues. The National Trust (1999) observed that 'renewable energy technologies are not necessarily environmentally-benign' whilst the Countryside Agency (1999) stated that 'while current and future generations have a need for clean energy, they also have a need for parts of the countryside to provide experiences of wildness and tranquillity'. As regards disruptions to nature, the effect on birds is one of the largest. A report prepared by BirdLife International (2002) reviewed the literature on wind farm impacts on birds and identified three main hazards: collision mortality, disturbance leading to displacement and direct loss of habitat. In offering guidance on environmental impact assessment, the report eschewed blanket judgements on the desirability of wind farms. However, it struck a cautious note regarding large wind farms (especially with giant turbines), and argued for cumulative impact assessments to study the consequences of having several wind 
farms in close proximity. In a crowded turbine landscape, a saturation threshold can be expected to emerge. These problems appear to have produced a shift in the position of the Royal Society for the Protection of Birds. Its Director of Conservation, Dr Mark Avery, stated in an address to the BWEA in March 2004 that 'the RSPB supports increased renewable energy generation as part of a balanced approach towards tackling climate change, which we see as the greatest threat to the world's wildlife. However, we will object to any wind farms that seriously threaten important populations of birds and their habitats' (http://www.rspb.org.uk/policy/ windfarms/turbulent.asp).

A wind farm saturation effect applies not just to fauna, but also to people. Organizations stressing the amenity value of unspoilt landscapes for human enjoyment have expressed reservations. The Open Spaces Society (2002) stated that it 'opposes the development of wind-turbine power-stations on common land, in view of their adverse effect on the open landscape and historical qualities of commons, the peace and quiet, and people's enjoyment of commons'. In summary, having been sucked into the wind power debate, these longstanding organizations seek to avoid compromising their original, nature conservation brief whilst acknowledging new challenges posed by the sustainability transition. Their dilemmas flag the fault-lines within environmentalist discourses on wind power.

\section{Anti-Wind Protest}

Because the value ascribed to wind depends on national and local circumstances, on a particular energy policy mix and on social configurations, which distinguish Britain, Denmark and France, the contours and mobilization tactics of the anti-wind movement in the three countries have also varied. In Denmark, it is represented by 'Neighbours against Windmills', which offers technical and legal advice to householders adversely affected by turbine installations.
However, probably because of the pro-wind societal consensus in Denmark, its activities seem fairly limited. However, in Britain and France two tiers of organized protest exist: local associations that fight specific planning applications, and national 'umbrella' organizations that put forward generic arguments related to energy policy and lobby national government.

Founded in 1992 in response to the NFFO, Country Guardian is the 'umbrella' organization for anti-wind protest in England and Wales. ${ }^{7}$ Country Guardian $(2000,2003)$ states that it is not opposed to wind energy as such, but in practice all sites that are windy enough for wind farms are environmentally sensitive in one way or another. In any case, the intermittency of wind power has shown it to be an ineffective source of electricity and it merely serves as an example of green tokenism, which does nothing to meet any environmental objectives'. It argues that wind is unreliable, produces insignificant quantities of electricity and its capacity for GHG reduction is trivial, yet still poses problems for integration into electricity systems. Its damaging impact on the environment is considered significant, with the 'industrialisation' of 'sensitive' landscapes by massive wind turbines (whose latest generation measures over a hundred metres in height, with rotor diameters of some 60 metres). Other negative features cited are harm to birds and to soil hydrology, nuisance and distress to local people (visual impact, noise), depressed house values near turbines and reduced amenity to the general public. Responding to climate change discourse, Country Guardian argues for GHG cuts by energy efficiency and demand side management ('we cannot reduce emissions whilst our consumption of energy grows' - Country Guardian, 2000). Finally, it uses the image of the 'white elephant' to claim that subsidies for wind power are ruinous. At the local level, examples of protest groups include 'Save

${ }^{7}$ For an insightful discussion of the Scottish case, see Strachan and Lal, 2004. 
the Vale' in Somerset, MAIWAG in Cumbria, the Cefn Croes Campaign in Wales and the Skye Wind Farm Action Group in Scotland. Such groups have variously sought to prevent wind farm construction and/or monitor their conformity with operating licences once built.

In France, the umbrella association Vent de Colère is unsparing in its critique of the feed-in tariff as being too high and generating undeserved profits at the taxpayer's expense. This is said to encourage speculation and greed, leading to conflict in rural communes. In 2001 alone proposed wind farm projects were estimated at some $13000 \mathrm{MW}$, and the scale of this 'wind rush' was the catalyst for the founding of Vent de Colère. Its advocacy in relation to energy supply and climate change is distinctive. Noting that $90 \%$ of French electricity is produced from GHG free sources, it argues that wind power brings no climate change bonus, since replacing nuclear or hydro with wind is GHG neutral (whilst fossil fuel facilities are still required to regulate the generation system and provide backup). As regards nuclear energy, the association observes that France's elite policy-makers continue to favour nuclear power, and seems to agree that wind cannot provide the exit sought by the anti-nuclear movement. The association advocates geothermal power for electricity generation and biofuels for vehicles. Like Country Guardian, Vent de Colère is critical that climate change policy has emphasized electricity generation rather than transport, the largest and most rapidly growing GHG source.

In summary, the anti-wind movement no longer dismisses climate change discourse. Campaigners tacitly acknowledge its hegemony, but redirect it in a way that allows them to accuse government of policy errors and wasting public funds. At the same time, protesters enter into direct conflict with developers by opposing wind farm planning proposals, leading to stalemate between the rival coalitions.

\section{Overview}

The wind power controversy may be considered as another variety of environmental conflict over development planning, comparable to disputes over transport infrastructure or siting of waste facilities. Well known conflict resolution and consensus-building solutions can be invoked, such as those indicated by Rydin (2003, p. 54), namely the identification of a common interest, negotiation for a compromise solution or a shift in the structure of interests. Such solutions have been explored in the literature and in practice. Aiming to build up common interests between developers and local people, Toke and Elliott (2000) recommended transplanting the Danish 'cooperative ownership model' into the British context. In practice, however, co-operative ownership remains under-developed, with the Baywind Energy Co-operative in Cumbria and Bro Ddyfi Community Renewables in Wales being rare and small exceptions. Negotiation for a compromise solution at the planning stage remains the most common resolution procedure, usually taking the form of a reduced number of turbines and/or adjustments in turbine alignment, distance from housing etc. However, currently proposals for 'mega-parks' (one hundred plus turbines) are being drawn up, which reduce the relevance of 'trimming' measures. Finally, there is the question of a shift in the structure of interests. Being a more fundamental type of adjustment, it is difficult to achieve. However, interests are themselves structured by perceptions and arguments, and here discourse analyses have a role to play.

In assessing discourse coalitions, this analysis has revealed not just polarization in relation to wind power, but also a split within 'green consciousness'. Pro-wind advocates claim they are 'saving the planet'. Anti-wind campaigners argue they are 'saving the environment'. Rival claims over the content of 'true green' are hardly new, as witnessed by the now dusty debate within ecology parties between 'fundis' 
and 'realos' (Doherty, 1992). What is relatively novel is the problematization within the energy sector of the same discourses, namely scientific arguments related to climate change and economic arguments related to technology choice. Because these source arguments are unable to settle the debate, the polarization of interests has been overlaid with an ethicalnormative frame that translates multi-layered decision-making into simplistic moral charges. The accusation made by the wind lobby can be summarized as follows: climate change is unwelcome, wind power helps prevent climate change, therefore its promotion is morally responsible and altruistic (being aimed at the benefit of the greater number) whilst resistance is reprehensible and selfish (being motivated by individual interest and 'NIMBYism'). Couched in this form, the weaknesses of the indictment leap to the eye. In a context where GHG emissions are rising, the contention that wind power helps prevent climate change remains notional. Moreover, the attribution of responsibility to rural communities for reliance on polluting technologies is particularly questionable when, on the one hand, traditional energy sources meet society-wide needs whilst, on the other, the energy companies who run wind farms often own fossil fuel or nuclear installations, meaning primary responsibility under the 'polluter pays' principle lies with them. In this context, anti-wind campaigners are outraged by the accusation that they lack moral fibre, and return the compliment by charges of corruption, profiteering, illegal construction and operation. ${ }^{8}$ Each side demonizes the other, resulting in a Manichean vision where the 'good' confront the 'bad'.

A long-term shift in the structure of interests would involve overcoming the various obstacles embedded in this arena. It requires greater recognition of the range of actors involved in sustainability debates. It implies closer inspection of the technological alternatives and policy

\footnotetext{
${ }^{8}$ Examples of such allegations can be found on the web sites of some anti-wind groups.
}

instruments, to bring in a broad spread of options as regards greater energy efficiency and the diversification of energy sourcing. It also involves re-evaluation of the role of communicative rationality over and against simplistic ethical-normative discourse. The energy debate would benefit from deliberative policy processes replacing sound-bite stigmatization of the 'adversary'. Clarification of the issues is desirable, notably a clear differentiation between actual cuts in GHG emissions (which occur when fossil fuel combustion is reduced), and notional avoidance, which is all that is achieved by simply adding wind capacity to current generation systems. The prevalent conflation of cuts and avoidance points to the need for more information and transparency to allow balanced and objective assessments. This in turn implies longer time frames for consultation and reflection. More ambitiously, the development of deliberative processes implies the design of institutional frameworks in which multiple options can be effectively evaluated in relation to each other, and implemented on a 'best case' basis. Meanwhile, a fundamental problem in the wind power controversy is the lack of local community experience of a range of energy pathways and the limited capacity to choose between alternatives. A top-down national government agenda, driven by international agreements, has often failed to engage communities, and so aroused distrust and opposition. The question for the future is whether this approach can provide an appropriate basis for a 'sustainability transition'.

\section{CONCLUSIONS}

In considering discourse coalitions related to wind power, this article has pointed to the stalemate that pertains when rival coalitions lay claim to similar environmentalist arguments but directed to different outcomes. It invites reassessment of the uses to which those arguments are put and offers tentative proposals for reducing blockages. 
First, although the scientific rationality of climate change diagnoses has been instrumentalized by various actors to justify their preferred ends, on its own it cannot provide policy solutions or confer political legitimacy. Within liberal market-oriented democracies, policy measures must be justified through other types of discourse: principally, economic rationality, ethical-normative values and communicative rationality. A broad finding of this study is that the interplay between these four discourse 'ideal types' remains under-theorized and poorly understood. A more specific finding is that the wind lobby has shown particular skill in side-stepping indeterminacies within the expert discourses of science and economics by appeal to an ethical-normative frame, e.g. stressing moral responsibilities related to climate change. An 'advocacy coalition' strategy bringing together an interest group (power companies, turbine manufacturers, developers etc) with civil society representatives (international NGOs) underpinned the credibility of this discourse and contributed to the lobby's success in gaining government support.

Second, the insistence on climate change justifications may in the longer term prove to be an 'Achilles heel'. As the wind sector comes under greater scrutiny, it will need to demonstrate that subsidies to wind power lead to actual cuts in GHG emissions, yet this can only happen by the phasing out of fossil fuel (or by its decarbonization). The sector may find it difficult to show (a) that this happens at all and (b) where it happens, that there is a direct, causal link with wind power expansion. Thus other arguments - such as responding to fuel scarcity, energy diversification and security of supply - may provide a sounder foundation for renewables.

Third, the one-sided emphasis on electricity generation - and on wind power in particular - has distorted societal communication, producing polarization and conflict. Rural communities find it hard to understand why rare and sensitive environments are sacrificed, in the face of negligible measures to curb GHG emissions elsewhere. However, social acceptance or rejection of wind power is not just a 'story line' about subjective or aesthetic reactions to large turbines in the landscape. At the heart of the debate is the question of meaningful choice over alternative development pathways, as well as lucidity over their consequences. All options have their downside.

Finally, societal choice requires responsive institutional frameworks and clear bases of legitimacy for concerned actors. However, ambiguity persists over whether in the future energy reform is to be achieved 'bottom up' by local consensus (which to a certain degree occurred in Denmark) or 'top down' by statecentred measures, as was traditionally the case in the centralized, 'bulk power' energy sectors of Britain and France. Moreover, if policy elites still opt for the latter, what is its feasibility given the decentralized or local character of most renewables? Here a specific planning issue for wind farms is whether they merit 'favoured status', or are treated like any another infra-structural project. The resolution of this issue may be a 'litmus test' in assessing changing patterns of governance within the energy sector. Such developments can illuminate whether the 'sustainability transition' is being enacted in terms of inclusion and deliberation, or in terms of new classes of social and political conflict.

\section{ACKNOWLEDGEMENTS}

The financial support of the British Academy for fieldwork interviews in Britain, Denmark and France in 2003-04 is gratefully acknowledged, and respondents are warmly thanked for their time and help. The anonymous reviewers are thanked for their constructive comments.

\section{REFERENCES}

Benard M. 1998. Electricity generation from renewable energy: the French experience, Renewable Energy 15: 264-269. 
BirdLife International/Langston RHW, Pullan JD. 2002. Wind Farms and Birds: an Analysis of the Effects of Wind Farms on Birds, and Guidance on Environmental Assessment Criteria and Site Selection Issues, T-PVS/Inf (2002) 30 revised. Council of Europe: Strasbourg.

Birraux C, Le Déaut J-Y. 2001. L'Etat Actuel et les Perspectives Techniques des Energies Renouvelables, rapport no. 3415. Office Parlementaire d'Evaluation des Choix Scientifiques et Technologiques/Assemblée Nationale: Paris.

Boehmer-Christiansen S, Kellow A. 2002. International Environmental Policy. Interests and the Failure of the Kyoto Process. Elgar: Cheltenham.

Brundt A, Spooner D. 1998. The development of wind power in Denmark and the UK. Energy and Environment 9(3): 279-296.

Country Guardian. 2000. What's Wrong with Windfarms? http://www.countryguardian.net/case.htm [18 February 2004].

Country Guardian. 2003. The Windfarm White Elephant. http:/ / www.countryguardian.net/The\%20windfarm\%20white\%20elephant.htm [18 February 2004].

Countryside Agency. 1999. Renewable Energy Developments. http://www.countryside.gov.uk/WhoWeAreAndWhatWeDo/boardMeetings/boardPapers/CA AP99_50.asp [26 February 2004].

Danish Environment and Energy Ministry. 1996. Energy 21. The Danish Government's Action Plan for Energy 1996. Danish Environment and Energy Ministry: Copenhagen.

Danish Environment and Energy Ministry. 1999. FollowUp on Energy 21: Status of Energy Planning. Danish Environment and Energy Ministry: Copenhagen.

Danish Government. 2002. Liberalisation of the Energy Markets. Danish Ministry of Economic and Business Affairs: Copenhagen.

Danish Government. 2003. Proposal for a Climate Strategy for Denmark. http:/ / www.mst.dk [8 July 2003].

de Gouvello C. 2002. France: focus on non-fossil fuels. In Vrolijk C (ed.), Climate Change and Power: Economic Instruments for European Electricity. Earthscan: London; 131-147.

Doherty B. 1992. The fundi-realo controversy: an analysis of four European Green parties. Environmental Politics 1(1): 95-120.

Dryzek JS. 1997. The Politics of the Earth: Environmental Discourses. Oxford University Press: Oxford.

English Nature RSPB, WWF-UK BWEA. 2001. Wind Farm Development and Nature Conservation. A Guidance Document for Nature Conservation Organisations and Developers when Consulting over Wind Farm Proposals in England. http://www.wwf.org.uk/filelibrary/pdf/wind_ farm4.pdf [17 June 2003].

EWEA, Greenpeace. 2003. Wind Force 12: a Blueprint to Achieve 12\% of the World's Electricity from Wind Power by 2020. EWEA-Greenpeace: Brussels.
Fischer F, Forester J (eds). 1993. The Argumentative Turn in Policy Analysis and Planning. Duke University Press: Durham.

FoE. 2002. Wind Power: Your Questions Answered. FoE: London.

Gipe P. 1995. Wind Energy Comes of Age. Wiley: New York. Gouvernement Français. 2000. Programme National de Lutte Contre le Changement Climatique. République Française: Paris.

Grohenheit PE. 2002. Denmark: long-term planning with different objectives. In Vrolijk C (ed.), Climate Change and Power: Economic Instruments for European Electricity. Earthscan: London; 108-130.

Hajer MA. 1993. Discourse coalitions and the institutionalisation of practice. In Fischer F, Forester J (eds), The Argumentative Turn in Policy Analysis and Planning. Duke University Press: Durham; 43-76.

Hajer MA. 1995. The Politics of Environmental Discourse: Ecological Modernization and the Policy Process. Clarendon: Oxford.

Helm D. 2002. A critique of renewables policy in the UK. Energy Policy 30(3): 185-188.

International Energy Agency (IEA). 2003. Wind Energy Annual Report 2002. IEA: Paris.

Jørgensen U, Karnøe P. 1995. The Danish wind-turbine story: technical solutions to political visions. In Rip AR, Misa TJ, Schot J (eds), Managing Technology in Society. The Approach of Constructive Technology Assessment. Pinter: London; 57-82.

Laali A-R, Benard M. 1999. French wind power generation programme EOLE 2005: results of the first call for tenders. Renewable Energy 16: 805-810.

Majone G. 1989. Evidence, Argument and Persuasion in the Policy Process. Yale University Press: New Haven, CT.

Meadows DL, Randers J, Behrens WW. 1972. The Limits to Growth. A Report for the Club of Rome's Project on the Predicament of Mankind. Pan: London.

Mitchell C. 1995. The renewables NFFO. Energy Policy 23(12): 1077-1091.

Mitchell C. 2000. The England and Wales non-fossil fuel obligation: history and lessons. Annual Review of Energy and the Environment 25: 285-312.

National Trust. 1999. Executive committee 28 January 1999. http://www.nationaltrust.org.uk/ environment/html/env_iss/_fspapers/fs_envissu4. htm [26 February 2004].

Nielsen FB. 2002. A formula for success in Denmark. In Pasqualetti MJ, Gipe RW, Righter RW (eds), Wind Power in View: Energy Landscapes in a Crowded World. Academic: London; 115-132.

Open Spaces Society. 2002. Policy on Wind Turbines. http://www.oss.org.uk/publications/infosht/a4.htm [17 June 2003].

Parker M. 2002. A low carbon energy policy for the UK under conditions of uncertainty. In Helm D (ed.), 
Towards an Energy Policy: The PIU Report and the White Paper. Oxera: Oxford; 31-41.

Rein M, Schön D. 1993. Reframing policy discourse. In Fischer F, Forester J (eds), The Argumentative Turn in Policy Analysis and Planning. Duke University Press: Durham; 145-166.

Rydin Y. 2003. Conflict, Consensus and Rationality in Environmental Planning: an Institutional Discourse Approach. Oxford University Press: Oxford.

Sabatier P, Jenkins-Smith HC. 1999. The advocacy coalition framework: an assessment. In Sabatier P (ed), Theories of the Policy Process. Westview: Boulder, CO; 117-166.
Secretary of State for Trade and Industry. 2003. Our Energy Future - Creating a Low Carbon Economy, Cm 5761.

Steen N, Vrolijk C. 2002. United Kingdom: power markets and market policies. In Vrolijk C (ed.), Climate Change and Power: Economic Instruments for European Electricity. Earthscan: London; 224-256.

Strachan PA, Lal D. 2004. Wind energy policy, planning and management practice in the UK: hot air or gathering storm? Regional Studies 38(5): 551-571.

Toke D, Elliott D. 2000. A fresh start for UK wind power? International Journal of Ambient Energy 21(2): 67-76.

Wind Directions. 2004. May-June. 